\title{
Impact of Pesticides Borate and Imidacloprid on Insect Emergence from Logs Infested by the Emerald Ash Borer
}

\author{
Pascal Nzokou, Samuel Tourtellot, and D. Pascal Kamdem
}

\begin{abstract}
The Emerald Ash Borer (EAB) was discovered on North American soil in the summer of 2002 near Detroit, Michigan, U.S., and has since spread to six states/provinces. To alleviate these costs, a method of sanitization is urgently needed. This study evaluated four different chemical sanitation methods in laboratory and field conditions. Treatments included two borate treatments, spray and dip, with concentrations ranging from $5 \%$ to $16.5 \%$ boric acid equivalents by mass and Preventol ${ }^{\circledR}$, a technical grade imidacloprid treatment with solution concentrations ranging from $0.005 \%$ to $0.02 \%$ applied as sprays. When logs were reared indoors subsequent to treatment, the technical grade imidacloprid and the borate dip treatments reduced the infection levels significantly. For the outdoor-reared logs, only the technical grade imidacloprid had a significant effect. All chemical treatments did better under indoor rearing than they did under outdoor rearing. This has heavy implications for the development of a sanitization treatment to be used in actual applications. Observations of EAB adults after emergence indicate that borate treatments may negatively affect EAB adult health and survivability after emergence.
\end{abstract}

Key Words. Agrilus; borate; Emerald Ash Borer; exotic pests; imidacloprid; quarantine; sanitization; value added.

The Emerald Ash Borer (EAB), Agrilus planipennis (Coleoptera: Buprestidae), is a beetle whose native range encompasses Japan, Taiwan, the Korean Peninsula, eastern China and Mongolia, and southeastern Russia. In the summer of 2002, the EAB Agrilus planipennis (Coleoptera: Buprestidae) was discovered on dying ash trees near Detroit, Michigan, U.S. Since then, this insect has been found infesting ash trees in the majority of counties in the Lower Peninsula of Michigan as well as in isolated infestations in Michigan's Upper Peninsula, Illinois, Indiana, Ohio, Maryland, and Ontario, Canada, adding the EAB to the rapidly widening list of exotic, invasive insect epidemics that threaten the ecology and economies of North America and the World. According to the 2005 U.S. Forest Service Forest Inventory Analysis, there are 850 million ash trees existing in Michigan of which an estimated 25 million, roughly $2 \%$, are currently infected (Poland and McCullough 2006). Throughout the United States, at risk are more than eight billion ash trees comprising 16 species and approximately $7.5 \%$ of the nation's hardwood volume (Poland and McCullough 2006).

The EAB biology and mode of action has been clearly described in several studies (Bauer et al. 2003; Cappaert et al. 2004; Nzokou et al. 2006). EAB spend the majority of their life cycle under the bark of infested ash trees. This fact, along with the number of isolated EAB infestations, make it clear that the beetle is well adapted to human-aided spread, which has been its primary dispersal mechanism. A number of outbreaks have been traced to the movement of firewood, nursery stock, and possibly to other human-aided distribution mechanisms (McCullough et al. 2004; Marchant 2005; Waltz 2005). For this reason, a quarantine restricting the movement of EAB, ash logs, and all articles or products capable of containing EAB out of or through all infestation areas is one of the primary containment strategies being used by agencies in affected areas. This has seriously limited the ability of large and small scale wood product manu- facturers to develop value from infested ash wood, and most of the trees removed have been chipped and burned for energy cogeneration.

Our team has been investigating approaches able to sanitize infested ash products to allow free circulation in and out of quarantine zones to areas where value-added uses could be derived from ash wood products. Chemical treatments with borate and a technical grade of imidacloprid (Preventol ${ }^{\circledR}$; Bayer, Pittsburgh, PA) were evaluated for effectiveness in controlling postharvest emergence of EAB insects (Nzokou et al. 2006). Imidacloprid was chosen because of its promising performance in a number of previous studies applied as basal drenches, trunk injections, and direct bark sprays (Haack and Petrice 2004; McCullough et al. 2005; Smitley et al. 2005). Borate was chosen because of its relatively low toxicity to humans and the environment and successful use in several insecticidal applications (Anonymous 2004; Cox 2004).

Results obtained in a preliminary study (Nzokou et al. 2006) showed that Preventol ${ }^{\circledR}$ concentrations ranging from $0.05 \%$ to $0.001 \%$ by weight were able to fully sanitize infested logs used in the study. The lowest concentration used was effective, suggesting the optimum threshold could be even lower than $0.001 \%$. Borate (disodium octaborate tetrahydrate [DOT]) with concentrations ranging from $1.02 \%$ to $5.52 \%$ by weight boric acid equivalent (BAE) failed to fully control the insect emergence. However, the higher BAE concentrations produced a significant reduction in insect emergence, and we speculated that slightly higher borate concentrations will be effective. In addition, the results described previously were obtained under laboratory conditions with wood materials never exposed to outdoor environmental conditions. However, under normal user conditions, treated $\operatorname{logs}$ and wood material will eventually be exposed to sunshine and rainfall, likely causing the leaching of applied chemicals into surrounding environments. Both chemicals are 
Table 1. Borate and imidacloprid concentration tested.

\begin{tabular}{llllcr}
\hline & \multicolumn{4}{c}{ Concentrations $(\%)$} \\
\cline { 2 - 5 } Treatment & Control & 1 & 2 & 3 & 4 \\
\hline DOT (BAE) & 0.0 & $6.2(5.0)$ & $9.6(8.0)$ & $12.5(10.0)$ & $20.8(16.5)$ \\
Preventol ${ }^{\circledR}(98 \%$ imidacloprid) & 0.0 & 0.005 & 0.008 & 0.01 & 0.02 \\
\hline
\end{tabular}

DOT $=$ disodium octoborate tetrahydrate; $\mathrm{BAE}=$ boric acid equivalent.

known to be soluble in water to some extent, with borate being more soluble in water than imidacloprid. We expect treated logs reared outdoors to have greater insect emergence compared with treated logs reared indoors as a result of chemical leaching and environmental degradation.

Finding appropriate and effective chemical treatment for infested materials will help reduce quarantine restrictions by controlling insect populations in infested trees and logs, allowing movement of resources to places where valued-added products can be developed.

The goal of this project was to investigate imidacloprid and borate treatment for sanitization of EAB-infested logs and to test the effectiveness of those treatments under field conditions. Results of this study could be used as a model to address sanitization challenges posed by other exotic insects in various parts of the United States and the world and promote the movement of previously infested logs for value-added uses.

\section{MATERIALS AND METHODS}

\section{Log Preparation}

Infested green $\operatorname{logs}$ measuring approximately $1 \mathrm{~m}(3.3 \mathrm{ft})$ in length were gathered from the stems of 11 trees harvested in a wood lot near Ann Arbor, Michigan. Before harvesting, infestation levels were checked by removing small portions of the bark at breast height with a bark knife and confirming the presence of galleries and larvae. Logs were labeled by tree and according to their position in the tree. Logs were assigned to different treatments so that treatment types (i.e., borate spray and imidacloprid) had the same mix of logs from the same groups of trees. The logs were then cut into two halves with one half assigned to an indoor rearing and the other to outdoor exposure. Four replicates were assigned to each treatment.

Before applying the treatments, each log was examined and existing $\mathrm{EAB}$ exit holes were marked. Log length and diameter was measured at three different points each and the average of these three measures used to compute the bark surface area.

\section{Treatments}

Four concentrations of borate, DOT, ranging from $6.2 \%$ to $20.8 \%$ by weight were used (Table 1 ). These correspond to $5 \%$ to $16.5 \%$ BAE. Solutions were prepared by dissolving the appropriate amount of Timbor ${ }^{\circledR}$ professional wettable powder (Nisus Corporation, Rockford, TN, 98\% DOT) in hot water at room temperature. The treatments were applied as spray using a garden sprayer or dip with logs dipped into the treating solution for $24 \mathrm{hr}$.

Solution concentrations tested for Preventol ${ }^{\circledR}$, a technical grade of imidacloprid from Bayer (98\% imidacloprid), ranged from $0.005 \%$ to $0.02 \%$ (Table 1), below and slightly above the lowest previously found successful level (Nzokou et al. 2006). Preventol ${ }^{\circledR}$ is a wettable powder, and treating solutions were prepared by dissolving the corresponding weight in water. Preventol ${ }^{\circledR}$ was applied by spraying the log only.

\section{Rearing}

Indoor and outdoor rearing processes were used in the study. Logs for indoor rearing were placed in cardboard rearing tubes with plastic lids at both ends as described by Nzokou et al. (2006). For smaller logs, tubes were $20.32 \mathrm{~cm}$ (8.13 in) in diameter with a wall thickness of $9.25 \mathrm{~mm}(0.37 \mathrm{in})$; for logs too large to be reared in these tubes, $30.5 \mathrm{~cm}$ (12.2 in) diameter tubes were used with a $6.35 \mathrm{~mm}(0.25 \mathrm{in})$ thick wall. A circular hole was cut in each lid, and fine-mesh screening was glued over the hole. A small circular hole was then cut in the screening over which the lid of a screw cup with a similar-sized hole was glued. A screw cup was then attached to each lid (Figure 1). The screening allowed air circulation and light into the tube, and the mounted cups collected the EAB adults as they emerged. The tubes containing bolts were then incubated at ambient indoor conditions with constant lighting.

Outdoor logs were placed in a wooden cage with the frame completely enclosed by the fine-mesh screening (Figure 2). Plastic tubs were placed beneath the enclosures to collect and measure chemical leachate from samples after rainfall events. The data from leachate analysis will be published in a separate report.

\section{Data Collection}

For the indoor logs, rearing tubes were checked daily. All insects were collected in separate screw cups and labeled by the date found and log identifier. Ash leaves were inserted in each cup to provide food and the cups were then checked daily to measure the survival longevity of the emerged beetles for each treatment. After emergence had stopped, the rearing tubes were opened and the dead insects that had remained in the tube were collected and counted. The tubes were resealed and were evaluated again in the summer of 2007 for further emergence. This assessed the ability

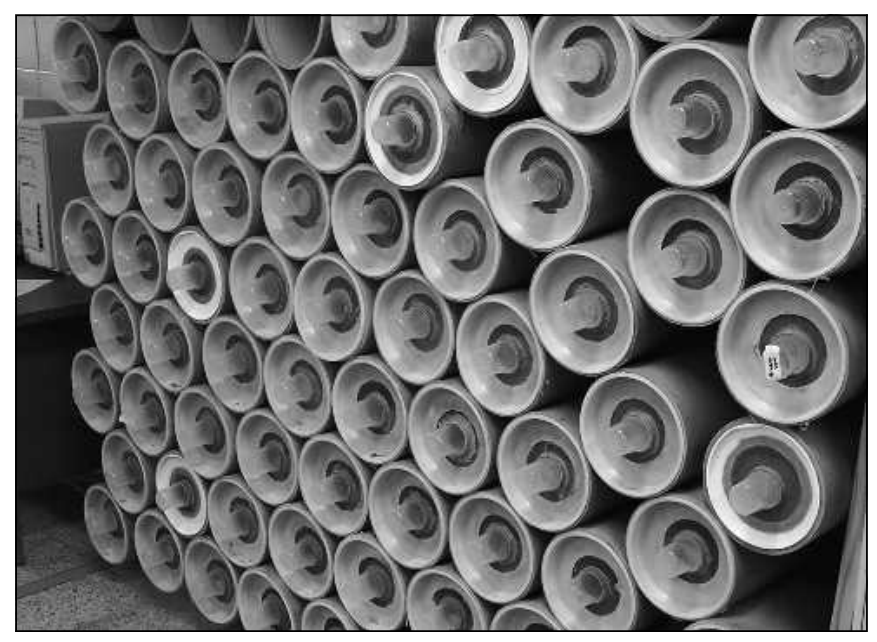

Figure 1. Cardboard rearing tube with collection cup for collecting Emerald Ash Borer adults. 


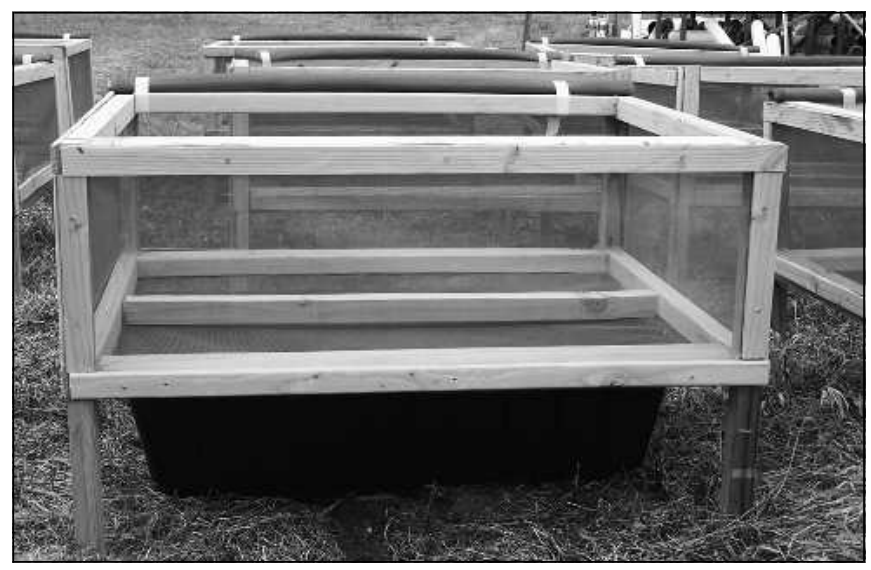

Figure 2. Mesh enclosure setup for containment and collection of Emerald Ash Borer adults in outdoor treatments.

of the logs to sustain a second generation or EAB with a 2-year life cycle or a second generation.

Outdoor rearing enclosures were checked for adult EAB weekly to roughly track the progress of emergence. Once new emergence stopped and all adults trapped inside the enclosure were dead, the enclosures were opened and the numbers of dead $\mathrm{EAB}$ were recorded. The numbers of new exit holes were also counted.

\section{Data Analysis}

EAB adult mean emergence density (MED) was calculated for each $\log$ as the mean number of emerged insects per square meter. A $\log 10$ transformation was applied to the data. MED values were compared between different concentrations of the same chemical and rearing conditions using a one-way analysis of variance (ANOVA, Puerto RicoC GLM, SAS version 9.1; SAS Institute Inc., Cary, NC). If the ANOVA was significant at a multicomparison-adjusted 0.017 level, Dunnett's procedure was used to compare the treatments with the control. To compare the performance of the different treatments when reared indoors with their performance when reared outdoors, the mean difference between all corresponding noncontrol indoor and outdoorreared $\operatorname{logs}$ treated with a given chemical was calculated using the untransformed data. This value was then compared with an expected value of zero using a paired t-test at a significance level of 0.017 .

To evaluate survival data, the mean survival period of adult EAB was computed. These values were then used in a one-way ANOVA test and when significant at a level of 0.05 . The means were separated using the Tukey-Kramer procedure. A log transformation was not appropriate for these data.

\section{Emergence Density}

The MED values for indoors and outdoors rearing tests are summarized in Table 2.

For logs reared indoors, Preventol ${ }^{\circledR}$ treatments resulted in MED ranging from 0 to 11.67 insects per square meter (ipsm) compared with untreated logs that had MED of $66.41 \mathrm{ipsm}$. The borate dip treatment also produced substantial reduction in MED with values ranging from 0 to 24.48 ipsm compared with 75.32
Table 2. Mean Emerald Ash Borer emergence densities (with standard errors in parentheses) for all chemical-treated logs reared indoors and outdoors. ${ }^{2}$

\begin{tabular}{lccc}
\hline & & \multicolumn{2}{c}{$\begin{array}{c}\text { Mean emergence density } \\
\text { (insects/m²) with standard error }\end{array}$} \\
\cline { 3 - 4 } Treatment & Concentration & Indoors & Outdoors \\
\hline Preventol ${ }^{\circledR}$ & Control & $66.41(7.52)$ & $75.97(22.26)$ \\
& $0.005 \%$ & $2.75(1.67)^{*}$ & $16.50(12.31)$ \\
& $0.008 \%$ & $11.62(11.62)^{*}$ & $17.60(11.29)$ \\
& $0.01 \%$ & $0.00(0.00)^{*}$ & $0.00(0.00)^{*}$ \\
Borate dip & $0.02 \%$ & $3.12(3.12)^{*}$ & $6.07(3.96)^{*}$ \\
& Control & $75.32(17.40)$ & $67.72(24.35)$ \\
& $5 \%(6.2 \%)^{y}$ & $0.00(0.00)^{*}$ & $23.39(3.80)$ \\
& $8 \%(9.6 \%)$ & $24.48(9.69)$ & $55.41(1.06)$ \\
Borate spray & $6.85(6.85)^{*}$ & $33.33(5.55)$ \\
& $10 \%(12.5 \%)$ & $11.06(5.38)^{*}$ & $39.20(13.39)$ \\
& $16.5 \%(20.8 \%)$ & $39.73(24.07)$ & $55.15(25.54)$ \\
& Control & $39.93(23.95)$ & $65.03(42.09)$ \\
& $5 \%(6.2 \%)$ & $42.26(19.56)$ & $79.45(38.83)$ \\
& $8 \%(9.6 \%)$ & $28.41(13.03)$ & $47.27(29.59)$ \\
& $10 \%(12.5 \%)$ & $26.78(13.00)$ & $66.79(23.48)$
\end{tabular}

${ }^{\mathrm{z}}$ Mean emergence densities that are significantly lower than their control at a significance level of 0.017 are marked with an asterisk $(*)$.

${ }^{\mathrm{y} B o r a t e}$ dip and borate spray concentrations displayed as percent boric acid equivalent with percent disodium octoborate tetrahydrate in parentheses.

ipsm for untreated control. MED averages for the borate spray treatment were between 26.78 and $42.26 \mathrm{ipsm}$ with their control set having an MED value of $39.73 \mathrm{ipsm}$. Both Preventol ${ }^{\circledR}$ and borate dip treatments had solution concentrations that resulted in zero MED $\left(0.01 \%\right.$ for Preventol ${ }^{\circledR}$ and 5\% BAE [6.2\% DOT)] for the borate dip); however, higher concentrations did not result in complete control of the infestation in both cases, indicating that serious care must be taken in recommending these treatments. The goal of the chemical treatment should be to achieve $100 \%$ control, and statistically significant reduction of insect emergence will not result in recommending the treatment because it will still result in some level of spread. The results indicate that borate concentrations up to $16 \% \mathrm{BAE}$ are not fully effective either as a spray or as a dip for controlling the EAB larvae from infested logs. In a previous study, full control with concentrations of $0.02 \%$ and $0.01 \%$ was obtained. However, in the current study, full control was obtained only with $0.01 \%$ with one insect emerging from the $0.02 \%$ logs. We are hypothesizing that the single emergence may be the result of uneven distribution of the chemical on the bark surface. However, if Preventol ${ }^{\circledR}$ was to be used for treatment of infested logs, it will be recommended to use higher concentrations of $0.04 \%$ or $0.05 \%$ to allow for a safety factor that will ensure complete killing of all EAB insects.

Statistical analysis showed that Preventol ${ }^{\circledR}$ treatments $(P=$ $0.0011)$ and borate dip treatments $(P=0.0005)$ resulted in significant decreases in MED, whereas borate spray treatments $(P=0.9680)$ did not. The Dunnett's procedure showed that all Preventol $^{\circledR}$ concentrations resulted in MED that were significantly different than the control group; all borate concentrations except for the $8 \%$ BAE (9.6\% DOT) solution were found to produce results significantly different from their control group.

When logs were reared outdoors, similar trends in the MED levels of the treatments were observed. Preventol ${ }^{\circledR}$ again produced the largest drops in insect emergence density compared 


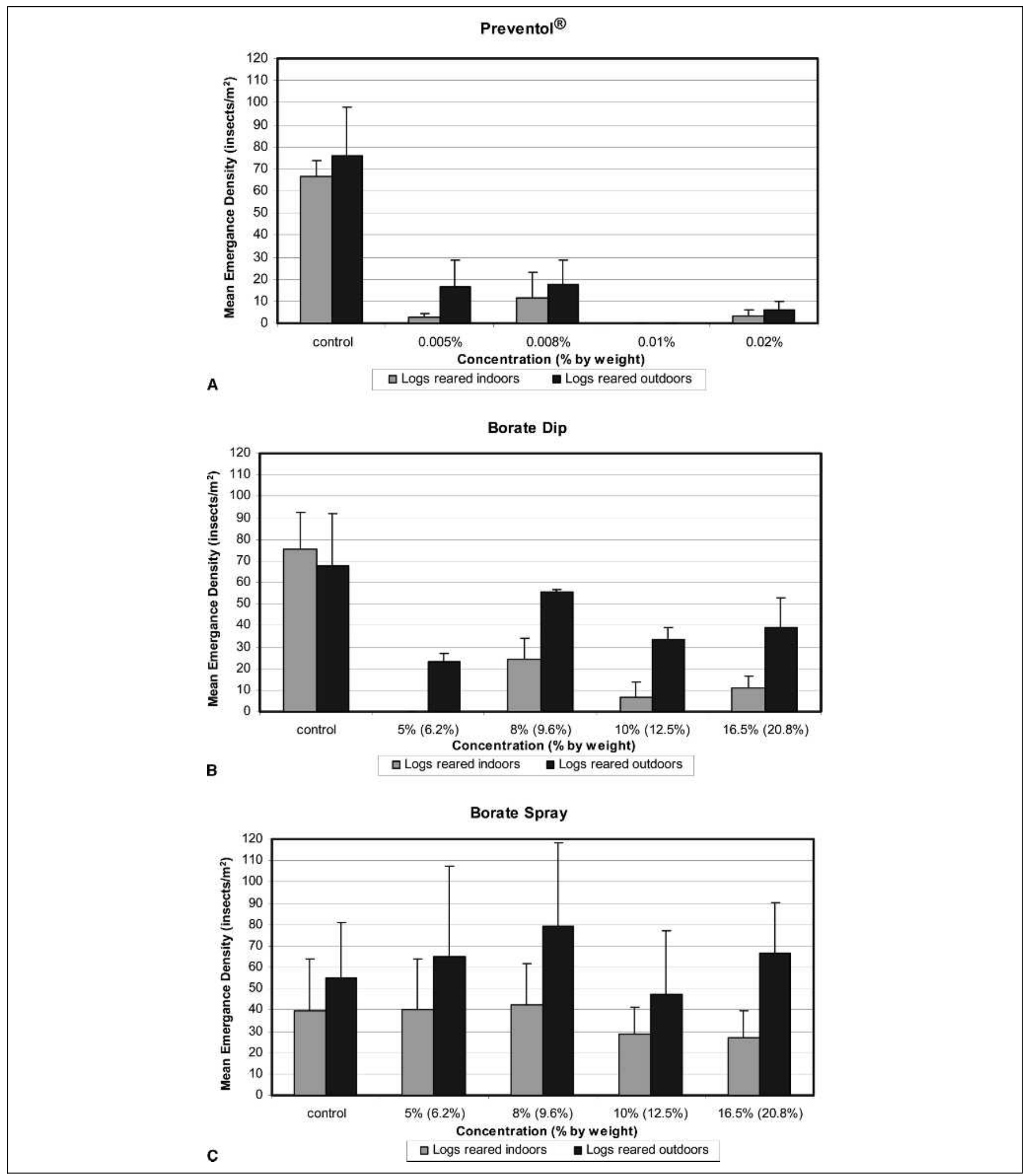

Figure 3. Mean Emerald Ash Borer emergence densities (MED) from logs treated with different concentrations of chemicals and subsequently reared either indoors or outdoors; standard error bars are included (A). Preventol ${ }^{\circledR}$ spray (B). Borate dip (C).

with the control group with MED values from 0 to $17.60 \mathrm{ipsm}$ compared with a control mean of $75.97 \mathrm{ipsm}$. The borate dip treatment also appears to have had a substantial effect on $\log$ infestation levels. Resulting treatment means ranged from 23.39 to $55.41 \mathrm{ipsm}$; the MED of the control was 67.72 . The borate spray treatment again had little or no effect on outdoor-reared logs. Borate spray treatment means were, in fact, generally higher than the control. Treatment means were measured from 
47.27 to $79.45 \mathrm{ipsm}$, whereas the control group MED was 55.15 ipsm.

The statistical analysis showed that only the Preventol ${ }^{\circledR}$ treatments produced significant reductions in MED from treated logs $(P=0.0154)$. The borate dip treatment $(P=0.4863)$ and borate spray treatment $(P=0.7972)$ failed to produce statistically significant effects. Dunnett's procedure showed that the MED of logs treated with Preventol ${ }^{\circledR}$ solution concentrations of $0.01 \%$ and $0.02 \%$ were significantly different from the control, whereas the two lower concentrations were not.

Figure 3 presents a side-by-side comparison of the indoor and outdoor rearing methods for each treatment. The figure shows that indoor rearing consistently produced higher reductions in MED compared with the corresponding outdoor treatments. When statistical tests were applied to the data, the borate dip $(P<0.0001)$ and borate spray $(P=0.0017)$ treatments showed that indoor rearing resulted in emergence levels that were significantly lower than those of outdoor rearing. The Preventol ${ }^{\circledR}$ treatment test produced a $P$ value of 0.1597 . These are the expected results considering the solubility of the two substances. We believe these data strongly support our hypothesis that exposure to rainfall and sunlight decreases the effectiveness of chemical log treatments. Protection against the weather is therefore strongly recommended if any insecticide treatment applied to the bark is considered for sanitization.

In a previous study, it was observed that a number $\mathrm{EAB}$ adults died while emerging from treated logs (Nzokou et al. 2006), suggesting that ingestion of the chemicals while burrowing out of the wood may be partially responsible for the insect mortality in both insecticides used. This phenomenon may have contributed to the reduction in effectiveness of the outdoor rearing trials. If the chemicals are washed out or diluted by rain, higher MED values would be expected. A potential improvement could be to adjust the timing of applications to decrease the time gap between application and emergence. Repeated applications throughout the emergence period could be an improvement as well but would have the drawback of increasing labor and material costs. Another option that might increase the effectiveness of the chemical treatments is using a carrier that works as a bark penetrant. This way it may be possible to reach all larvae in the cambium and outer sapwood forgoing the need to depend on the residual chemical remaining in the outer bark. This may also increase the level of chemicals in the bark and increase the mortality resulting from ingestion while exiting. In a previous study, a surfactant, Pentra, was used for this purpose and was shown to significantly increase imidacloprid residue in xylem sap (Cappaert et al. 2004b).

\section{Survival Longevity}

Table 3 displays the survival longevity data collected. Preventol $^{\circledR}$ failed to cause significant reductions in the survival longevity of adult $\mathrm{EAB}$ once they had emerged $(P=0.5261)$. The borate spray treatment, on the other hand, seemed to result in a noticeable and highly significant result $(P<0.0001)$, indicating that borate chemicals applied to larval EAB may have a lasting effect on the vigor and health of surviving adults. The TukeyKramer test found that all concentrations used except the second highest, $10 \% \mathrm{BAE}$, were significantly different from the control. This experiment was not set up to thoroughly study the chemical's effects on surviving adults. Survival data could not be gathered from logs reared outdoors for comparison. The data
Table 3. Survival longevity of adult Emerald Ash Borers (with standard errors in parentheses), in number of days, after emerging from logs treated chemically to eliminate infestation. ${ }^{2}$

\begin{tabular}{llll}
\hline Treatment & Concentration & Sample size & $\begin{array}{l}\text { Mean survival period } \\
\text { (no. of days) }\end{array}$ \\
\hline Preventol $^{\circledR}$ & Control & 31 & $10.55(1.06)$ \\
& $0.005 \%$ & 0 & - \\
& $0.008 \%$ & 5 & $8.80(1.62)$ \\
& $0.01 \%$ & 0 & - \\
Borate spray & $0.02 \%$ & 0 & - \\
& Control & 34 & $10.76(0.82)$ \\
& $5 \%(6.2 \%)^{\mathrm{y}}$ & 23 & $4.74(0.56)^{*}$ \\
& $8 \%(9.6 \%)$ & 16 & $6.69(0.86)^{*}$ \\
& $10 \%(12.5 \%)$ & 3 & $7.00(0.82)$ \\
& $16.5 \%(20.8 \%)$ & 6 & $3.67(1.56)^{*}$ \\
\hline
\end{tabular}

${ }^{\mathrm{z}}$ Mean survival periods that are significantly lower than their control at a significance level of 0.017 are marked with an asterisk $(*)$.

${ }^{\mathrm{y}}$ Borate spray concentrations displayed as percent boric acid equivalent with percent disodium octoborate tetrahydrate in parentheses.

presented here indicate a potential effect and needs to be investigated further before any conclusions can be made.

\section{CONCLUSIONS}

Borate and imidacloprid formulations were tested for the sanitization of logs infested by the EAB. Results obtained confirmed previous findings that a technical grade of imidacloprid insecticide (Preventol ${ }^{\circledR}$ ) is a very effective chemical treatment for the sanitization of EAB-infested logs. However, Results suggest that solution concentrations above $0.02 \%$ by weight are required. Levels of $0.04 \%$ and $0.05 \%$ are suggested to allow for a safety factor. Borate treatments at concentrations up to $16.5 \% \mathrm{BAE}$ were not successful in controlling EAB. Results also showed that treating logs and subsequently rearing them outdoors results in reduced effectiveness for all chemical treatments used, indicating that treated logs will have to be protected against rainfall when chemicals are used by applying them to the bark.

Acknowledgments. This research project was funded by a grant from the USDA Forest Service, Wood Education \& Resource Center through the Southeast Michigan Research and Development Council (SEMIRCD). We acknowledge support from the Michigan Department of Natural Resources and the Department of Forestry at Michigan State University.

\section{LITERATURE CITED}

Anonymous. 2004. Tim-bor Professional. Material Safety Data Sheet. The Nisus Corp., Rockford, TN. 1 pp.

Bauer, L.S., R.A. Haack, D.L. Miller, T.R. Petrice, and L. Houping. 2003. Emerald Ash Borer life cycle. In Masto, V., and R. Reardon (Eds.). Proceeding of the Emerald Ash Borer Research and Technology Development Meeting. FHTET-2004-02, USDA USFS APHIS, Morgantown, WV.

Cappaert, D.L., D.G. McCullough, and T.M. Poland. 2004a. Emerald Ash Borer life cycle: A reassessment. In Masto, V., and R. Reardon (Eds.). Proceeding of the Emerald Ash Borer Research and Technology Development Meeting. FHTET-2004-16, USDA USFS APHIS, Morgantown, WV.

Cappaert, D.L., D.G. McCullough, T.M. Poland, and L.P. Molongoski. 2004b. Non-invasive neonicotinoids: Treatments for ash logs and trees. In Masto, V., and R. Reardon (Eds.). Proceeding of the Emerald 
Ash Borer Research and Technology Development Meeting. FHTET2004-15, USDA USFS APHIS, Morgantown, WV.

Cox, C. 2004. Pesticide factsheet, boric acid and borates. Journal of Pesticide Reform 24:10-15.

Haack, R.A., and T.R. Petrice. 2004. Evaluation of various insecticides applied to the bark to control Emerald Ash Borer. In Masto, V., and R. Reardon (Eds.). Proceeding of the Emerald Ash Borer Research and Technology Development Meeting. FHTET-2004-15, USDA USFS APHIS, Morgantown, WV.

Marchant, K.R. 2005. Managing the Emerald Ash Borer in Canada. In Masto, V., and R. Reardon (Eds.). Proceeding of the Emerald Ash Borer Research and Technology Development Meeting. FHTET2005-16, USDA USFS APHIS, Morgantown, WV.

McCullough, D.G., D.L. Cappaert, T.M. Poland, and L.P. Molongoski. 2005. Long term (three year) results of trunk injections for Emerald Ash Borer control in landscape ash trees. In Masto, V., and R. Reardon (Eds.). Proceeding of the Emerald Ash Borer Research and Technology Development Meeting. FHTET-2005-16, USDA USFS APHIS, Morgantown, WV.

McCullough, D.G., N.W. Siegert, T.M. Poland, D.L. Cappaert, F. Ivich, and D. Williams. 2004 Dispersal of Emerald Ash Borer at outlier sites: Three case studies. In Masto, V., and R. Reardon (Eds.). Proceeding of the Emerald Ash Borer Research and Technology Development Meeting. FHTET-2004-02, USDA USFS APHIS, Morgantown, WV

Nzokou, P., T.R. Petrice, R.A. Haack, and D.P. Kamdem. 2006. Borate and imidacloprid treatment of ash logs infested with the Emerald Ash Borer. Forest Products Journal 56:78-81.

Poland, T.M., and D.G. McCullough. 2006. Emerald Ash Borer: Invasion of the urban forest and the threat to North America's ash resource. Journal of Forestry 104:118-124.

Smitley, D.R., D. Herms, and E. Rebek. 2005. Timing of imidacloprid soil drenches for Emerald Ash Borer control. In Masto, V., and R. Reardon (Eds.). Proceeding of the Emerald Ash Borer Research and Technology Development Meeting. FHTET-2005-16, USDA USFS APHIS, Morgantown, WV.

Waltz, R.D. 2005. Indiana Emerald Ash Borer status report. In Masto, V., and R. Reardon (Eds.). Proceeding of the Emerald Ash Borer Research and Technology Development Meeting. FHTET-2004-02, USDA USFS APHIS, Morgantown, WV.

Pascal Nzokou (corresponding author)

Assistant Professor

Department of Forestry

Michigan State University

East Lansing, MI 48824, U.S.

nzokoupa@msu.edu

Samuel Tourtellot

Laboratory Assistant

Department of Forestry

Michigan State University

East Lansing, MI 48824, U.S.

Tourtel1@msu.edu

D. Pascal Kamdem

Professor

Department of Forestry

Michigan State University

East Lansing, MI 48824, U.S.

Kamdem@msu.edu

Résumé. L'agrile du frêne a été découvert en Amérique du Nord durant l'été 2002 près de Détroit au Michigan et s'est depuis disséminé dans six états et provinces. Afin de diminuer les coûts liés à cet insecte, une méthode de contrôle sanitaire est nécessaire de manière urgente. Cette étude évalue quatre méthodes différentes de contrôle sanitaire chimique en laboratoire et sur le terrain. Les traitements incluent deux traitements avec borate - par vaporisation et par trempage - avec des concentrations variant de 5 à $16,5 \%$ d'équivalence en poids d'acide borique - ainsi que le Preventol, un traitement par grade technique à base d'imidacloprid avec des concentrations de solutions variant de 0,005 à $0,02 \%$ appliquées par vaporisation. Lorsque les tiges étaient en laboratoire, les traitements par grade technique avec l'imidacloprid et par trempage avec le borate ont permis de diminuer les niveaux d'infection significativement. Pour les tiges traitées à l'extérieur sur le terrain, seul l'imidacloprid par grade technique avait un effet significatif. Le traitement chimique le plus efficace était le Preventol. Tous les traitements chimiques étaient plus efficaces sous des conditions de laboratoire que sous des conditions de terrain. Ceci a des implications lourdes pour le développement d'un traitement sanitaire qui peut être utilisé dans des applications présentes. Ceci suggère également que l'agrile du frêne dans sa forme actuelle peut être affectée par des résidus chimiques dans le bois. Les observations d'adultes d'agrile du frêne après leur émergence indiquent que les traitements par le borate peuvent négativement affecter la santé et le taux de survie après émergence de l'adulte de l'agrile du frêne.

Zusammenfassung. Im Sommer 2002 wurde der Eschenbohrer (EAB) in der Nähe von Detroit, Michigan, gefunden und hat sich seitdem in sechs Bundesstaaten ausgebreitet. Um diese Kosten zu begrenzen, wird dringend eine Methode der Bekämpfung gebraucht. Diese Studie bewertet vier verschiedene chemische Behandlungen in Laborund Feldversuchen. Die Behandlungen bestanden aus zwei BorBehandlungen, Spray und Dip, mit Konzentrationen von $5-16,5 \%$ BAE und Preventol, ein technische Imidacloprid-Behandlung mit Lösungskonzentrationen von $0,005-0,2 \%$, appliziert als Spray. Als die Stämme vor der Behandlung drinnen umgedreht wurden, reduzierten Imidacloprid und der Bor-Dip deutlich den Infektionslevel. Die draussen umgedrehten Stämme zeigten nur bei Imidacloprid eine signifikante Reaktion. Die größte Reaktion wurde von Preventol erzielt. Alle chemischen Behandlungen reagierten besser, wenn die Stämme zunächst drinnen gedreht wurden. Das hat einen großen Einfluss auf die Entwicklung von Behandlungsmethoden, die in der aktuellen Applikation verwendet werden. Es zeigt auch, dass die Vernichtung von EAB durch die chemischen Rückstände im Holz beeinflusst wird. Die Beobachtung von EAB-Käfern nach dem Schlüpfen zeigt, dass die Bor-Behandlungen einen negativen Einfluss auf die Gesundheit der Käfer und deren Überlebensrate nach dem Schlüpfen haben.

Resumen. El barrenador esmeralda del fresno (EAB, por sus siglas en inglés) fue descubierto en el suelo de Norte América en el verano de 2002 cerca de Detroit, Michigan y desde entonces se ha dispersado a 6 estados/provincias. Para aliviar estos costos se requiere con urgencia un método de saneamiento. Este estudio evaluó cuatro diferentes métodos químicos sanitarios en laboratorio y condiciones de campo. Los tratamientos incluyeron dos tratamientos con borato, aerosol y lavado, en concentraciones variando de 5 a $16.5 \%$ por masa, equivalentes de ácido bórico (BAE, por sus siglas en inglés) y Preventol, un tratamiento con imidacloprid con solución a concentraciones de 0.005 a $0.02 \%$ aplicado como aerosol. Cuando las trozas fueron dejadas adentro después del tratamiento, los tratamientos con imidacloprid, borato y baño redujeron los niveles de infección significativamente. Para las trozas en el campo, solamente el imidacloprid tuvo un efecto significativo. El tratamiento químico más efectivo fue Preventol. Todos los tratamientos químicos trabajaron mejor en el laboratorio que en el campo. Esto tiene fuertes implicaciones para el desarrollo de un tratamiento sanitario en condiciones reales. Esto también sugiere que las emergencias de EAB pueden ser afectadas por los químicos residuales en la madera. Las observaciones de $\mathrm{EAB}$ adultos después de la emergencia indican que los tratamientos con borato pueden afectar negativamente su salud y supervivencia. 